\title{
Le triangle du sens
}

A propos de Boris Cyrulnik, La Naissance du sens

\section{François Sigaut}

\section{(2) OpenEdition}

\section{Journals}

Édition électronique

URL : https://journals.openedition.org/tc/678

DOI : $10.4000 /$ tc. 678

ISSN : 1952-420X

Éditeur

Éditions de l'EHESS

\section{Édition imprimée}

Date de publication : 1 mai 1993

ISSN : 0248-6016

Référence électronique

François Sigaut, «Le triangle du sens », Techniques \& Culture [En ligne], 19 | 1993, mis en ligne le 10

janvier 2006, consulté le 29 septembre 2022. URL : http://journals.openedition.org/tc/678 ; DOI :

https://doi.org/10.4000/tc.678

Ce document a été généré automatiquement le 29 septembre 2022.

Tous droits réservés 


\section{Le triangle du sens}

A propos de Boris Cyrulnik, La Naissance du sens

François Sigaut 